DOI: https://doi.org/10.24127/ajpm.v8i3.2349

MENGAPA SULIT MENYELESAIKAN SOAL PECAHAN $\frac{2}{x}+\frac{3}{y}=\frac{2}{3}$ ?

\title{
Sugeng Sutiarso
}

\author{
Pendidikan Matematika, Universitas Lampung \\ E-mail: $\quad$ sugeng.sutiarso@fkip.unila.ac.id
}

Received 30 September 2019; Received in revised form 5 December 2019; Accepted 23 December 2019

\begin{abstract}
Abstrak
Penelitian ini bertujuan untuk mendeskripsikan kemampuan mahasiswa dan guru dalam menyelesaikan soal pecahan, dan mengetahui penyebab sulitnya menyelesaikan soal pecahan tersebut. Subjek penelitian terdiri dari 40 mahasiswa pendidikan matematika dan 30 guru matematika yang berasal dari kota/kabupaten di Propinsi Lampung. Data penelitian dikumpulkan melalui tes dan wawancara. Wawancara dilakukan untuk melengkapi data tentang penyebab sulitnya menyelesaikan masalah pecahan. Data penelitian dianalisis secara deskriftif. Hasil penelitian menyimpulkan bahwa (1) kemampuan mahasiswa dan guru dalam menyelesaikan soal pecahan berada pada level kurang, cukup, dan baik, dan (2) penyebab sulitnya mahasiswa dan guru menyelesaikan soal pecahan tersebut adalah sulitnya menyelesaikan soal dengan variabel lebih banyak daripada persamaan, memisahkan variabel $x$ dan $y$ pada sisi berbeda, dan tidak mendapatkan solusi bulat (real/imaginer). Selain itu, diperoleh temuan penting pada penelitian ini, yaitu masih kelemahan/kekurangan dalam memodifikasi bentuk aljabar, mencari berbagai alternatif penyelesaian soal, dan memisahkan dua variabel (x dan y). Kepada mahasiswa dan guru disarankan memahami konsep dan operasi pecahan lagi, serta melatih diri untuk kritis dan kreatif menyelesaikan soal pecahan.
\end{abstract}

Kata kunci: kesulitan; pecahan.

\begin{abstract}
This study aims to describe the ability of students and teachers to solve fraction problems, and find out why students or teachers are difficult to solve these problems. The research subjects consisted of 40 mathematics education students and 30 mathematics teachers from cities/districts in Lampung Province. Research data were collected through tests and interviews. Interview to complete the difficulty of solving the problem of fraction. The research data were analyzed descriptively. The results of the study concluded that (1) the ability of students and teachers to solve fraction questions is at a level that is lacking, sufficient, and good, and (2) the reason why it is difficult for students and teachers to solve the fraction problem is the difficulty of solving problems with more variables than quations, separating variables $x$ and $y$ on different sides, and not getting a round solution (real/imaginer). In addition, important findings obtained in this study, namely still weaknesses / deficiencies in modifying the form of algebra, looking for various alternative solutions to the problem, and separating the two variables ( $x$ and y). For students and teachers are advised to understand fraction concepts and operations again, and train themselves to critically and creatively solve fraction problems.
\end{abstract}

Keywords: difficulty; fraction.

\section{PENDAHULUAN}

Matematika adalah salah satu pelajaran yang diajarkan di sekolah, sejak SD hingga perguruan tinggi. Matematika memuat 3 bagian utama, yaitu aljabar, geometri, dan statistika. Pecahan merupakan salah satu materi pada bagian aljabar. Kemampuan siswa pada konsep pecahan sangat penting baik dalam kehidupan sehari-hari maupun matematika itu sendiri. Sebagian besar kehidupan sehari-hari tidak terlepas dari penggunaan pecahan, seperti memasak, pertukangan, olah raga, dan menjahit (Grossberg, 2017). Dalam pem-belajaran matematika di kelas, mempel-ajari pecahan bermanfaat untuk "helping students to achieve a 
DOI: https://doi.org/10.24127/ajpm.v8i3.2349

solid grounding in mathematics in general and in fractions in particular has long-term high-stakes ramifications"; artinya membantu siswa untuk mencapai dasar matematika yang kuat secara umum, khususnya pecahan yang memiliki percabangan ilmu yang luas (Bruce, Chang, \& Flynn, 2013). Jadi, hal ini berarti bahwa memperlajari pecahan sangat penting bagi siswa, dan materi ini sudah diajarkan kepada siswa mulai kelas 3 SD (Sutiarso, Asnawati, \& Jalil, 2017).

Pecahan memiliki empat jenis ope-rasi matematika jenis, yaitu penjumlahan, pengurangan, perkalian, dan pembagian (Koll \& Mills, 2015). Dalam proses penyelesaian suatu soal, operasi pecahan ini memiliki perbedaan dengan operasi matematika biasa, kecuali perkalian. Misalnya, untuk menyelesaikan pecahan $\frac{1}{2}+\frac{1}{4}=\ldots$ atau $\frac{1}{2}-\frac{1}{4}=\ldots$ maka terlebih dahulu harus menyamakan penyebutnya. Kondisi yang lebih berbeda pada soal $\frac{1}{2}: \frac{1}{4}=\ldots$ yang proses penyelesaianya lebih rumit lagi. Perbedaan pada proses penyelesaian inilah yang dianggap menjadi penyebab sulitnya siswa memahami ope-rasi pecahan.

Proses penyelesaian soal yang meli-batkan operasi pecahan mensyaratkan be-berapa kemampuan lain selain operasi itu sendiri. Seperti pada soal di atas, untuk menyelesaikan soal $\frac{1}{2}+\frac{1}{4}=\ldots$ maka terda-pat beberapa kemampuan yang diperlukan, seperti menentukan KPK (Kelipatan Persekutuan terKecil), menjumlahkan dua bilangan, membagi dua bilangan, dan menyederhakan pecahan. Bandingkan dengan operasi penjumlahan biasa, misalnya $2+4=\ldots$. yang tidak memerlukan banyak kemampuan, tapi hanya satu kemampuan saja yaitu menjumlahkan dua bilangan.

Beberapa cara telah dicontohkan oleh guru dalam mengajarkan pecahan kepada siswa. Cara mengajarkan pecahan itu antara lain mengajarkan pecahan melalui chart dan garis bilangan, melalui pendekatan ice-berg; meliputi empat tingkatan aktivitas, yakni orientasi lingkungan secara matematis, model material, pembuatan pondasi, dan matematika formal (Haji, 2013), melalui alat peraga timbangan (Rahmawati, 2017). Meskipun berbagai cara telah dilakukan guru dalam mengajarkan pecahan, namun siswa tetap mengalami kesulitan memahami pecahan.

Beberapa penelitian tentang pecahan telah dilakukan oleh peneliti pada siswa jenjang SD dan SMP dengan hasil bahwa siswa mengalami kesulitan pada materi pecahan. Pada jenjang SD, kesulitan siswa adalah melakukan operasi pecahan (Karmawati, 2010), memodifikasi operasi pecahan (Suryowati, 2015), memahami prosedur penjumlahan dan pengurangan pada penyebut yang berbeda (Trivena, Ningsih, \& Jupri, 2017). Pada jenjang SMP, kesulitan siswa adalah tidak dapat menyamakan penyebut atau salah memfaktorkan, salah menafsirkan prinsip pencoretan, tidak dapat menuliskan variabel, kesalahan melakukan operasi penjum-lahan, pengurangan, perkalian, atau pembagian, kesalahan dalam menuliskan tanda positif dan negatif (Sahriah \& Muksar, 2012), kesalahan operasi hitung, menyederhanakan pecahan, prosedur tidak lengkap, dan mengerjakan sembarang (Ramlah, Bennu, \& Paloloang, 2016). Berdasarkan beberapa hasil penelitian 
tersebut menunjukkan bahwa siswa SD dan SMP masih kesulitan dalam menyelesaikan pecahan.

Saat ini, penelitian tentang pecahan belum dilakukan oleh para peneliti untuk siswa jenjang SMA, mahasiswa, bahkan guru. Padahal pengetahuan kemampuan pecahan pada siswa SMA, mahasiswa,dan guru sangat diperlukan. Hal ini untuk memastikan apakah siswa jenjang SMA, mahasiswa, dan guru masih mengalami kesulitan pada materi pecahan?, dan apa sajakah penyebab sulitnya menyelesaikan soal pecahan?. Oleh karena itu, penelitian ini difokuskan untuk melihat kemampuan mahasiswa dan guru terhadap materi pecahan. Pemilihan mahasiswa dan guru didasarkan pada pertimbangan bahwa mahasiswa sebagai calon guru, dan guru adalah seseorang yang akan menyampaikan materi pecahan kepada siswanya. Berdasarkan uraian tersebut maka penelitian ini perlu dilakukan dengan tujuan untuk mendeskripsikan kemampuan mahasiswa dan guru dalam menyelesaikan soal pecahan, dan mengetahui penyebab sulit-nya menyelesaikan soal pecahan. Soal pecahan tersebut adalah "Tentukan $x$ and $y$ dari persamaan $\frac{2}{x}+\frac{3}{y}=\frac{2}{3} ; x, y \in$ Z ?". Penelitian ini diharapkan dapat bermanfaat kepada mahasiswa dan guru dalam meng-ajarkan materi pecahan, dan kepada penyusun kurikulum dalam menempatkan materi pecahan sesuai dengan usia kognitif yang tepat.

\section{METODE PENELITIAN}

Jenis penelitian ini adalah deskriptif kualitatif yang menjelaskan keadaan sebenarnya tanpa ada perlakuan terhadap subjek penelitian. Subjek penelitiannya adalah mahasiswa dan guru matematika, terdiri dari 40 mahasiswa program studi pendidikan matematika yang telah menempuh mata kuliah program linear tahun 2018/ 2019 dan 30 guru matematika yang berasal dari kota/kabupaten di Propinsi Lampung. Pemilihan mahasiswa dan guru ter-sebut didasarkan pada pertimbangan bahwa mahasiswa dan guru matematika telah menguasai konsep pecahan, bahkan guru juga mengajar konsep pecahan di sekolah.

Data penelitian diperoleh melalui tes dan wawancara. Tes untuk melihat ke-mampuan mahasiswa dan guru dalam me-nyelesaikan soal dan juga untuk menge-tahui penyebab sulitanya menyelesaikan soal. Soalnya adalah "Tentukan $\mathrm{x}$ dan $\mathrm{y}$ dari persamaan $\frac{2}{x}+\frac{3}{y}=\frac{2}{3} ; x, y \in Z \quad$ dengan waktu penyelesaian selama 60 menit. Hasil tes mahasiswa dan guru dan wawancara dianalisis secara deskriptif, dan diklasifikasikan atas lima level pada Tabel 1.

Tabel 1. Kriteria jawaban dan level kemampuan pecahan

\begin{tabular}{|c|c|c|}
\hline No. & Kriteria Jawaban & $\begin{array}{c}\text { Level } \\
\text { Kemampuan }\end{array}$ \\
\hline 1. & memberikan & $\begin{array}{c}\text { Sangat } \\
\text { Kurang }\end{array}$ \\
\hline 2. & Menjawab tidak selesai & Kurang \\
\hline 3. & Menjawab salah & Cukup \\
\hline 4. & $\begin{array}{l}\text { Menjawab benar secara } \\
\text { trial-error (coba-coba). }\end{array}$ & Baik \\
\hline 5. & $\begin{array}{l}\text { Menjawab benar secara } \\
\text { matematis }\end{array}$ & Sangat baik \\
\hline
\end{tabular}

\section{HASIL PENELITIAN DAN PEMBAHASAN}

1. Jawaban mahasiswa dan guru

Hasil analisis dari jawaban mahasiswa dan guru menyelesaikan soal "Ten-tukan $x$ dan y dari persamaan $\frac{2}{x}+\frac{3}{y}=\frac{2}{3} ; x, y \in Z$ diklasifikasikan atas lima bagian, yaitu menjawab benar 
DOI: https://doi.org/10.24127/ajpm.v8i3.2349

secara matematis, menjawab benar secara trial-error, menjawab salah, menjawab tidak selesai, dan tidak memberikan jawaban. Jawaban mahasiswa dan guru disajikan pada Tabel 2.

Tabel 2. Jawaban mahasiswa dan guru

\begin{tabular}{|c|c|c|c|}
\hline \multirow[b]{2}{*}{ No. } & \multirow{2}{*}{$\begin{array}{l}\text { Kriteria } \\
\text { Jawaban }\end{array}$} & \multicolumn{2}{|c|}{ Jawaban } \\
\hline & & $\begin{array}{c}\text { Mahasiswa } \\
(\%)\end{array}$ & $\begin{array}{c}\text { Guru } \\
(\%)\end{array}$ \\
\hline 1. & $\begin{array}{l}\text { Tidak } \\
\text { memberi-kan } \\
\text { jawaban }\end{array}$ & 0 & 0 \\
\hline 2. & $\begin{array}{l}\text { Menjawab } \\
\text { tidak selesai }\end{array}$ & $\begin{array}{c}14 \\
(35 \%)\end{array}$ & $\begin{array}{c}20 \\
(66,7 \%)\end{array}$ \\
\hline 3. & $\begin{array}{l}\text { Menjawab } \\
\text { salah }\end{array}$ & $\begin{array}{c}9 \\
(22,5 \%)\end{array}$ & $\begin{array}{c}6 \\
(20 \%)\end{array}$ \\
\hline 4. & $\begin{array}{l}\text { Menjawab } \\
\text { benar secara } \\
\text { trial-error }\end{array}$ & $\begin{array}{c}17 \\
(42,5 \%)\end{array}$ & $\begin{array}{c}4 \\
(13,3 \%)\end{array}$ \\
\hline 5. & $\begin{array}{l}\text { Menjawab } \\
\text { tidak selesai }\end{array}$ & 0 & 0 \\
\hline
\end{tabular}

Berdasarkan Tabel 2, diperoleh

beberapa temuan bahwa semua mahasiswa dan guru tidak dapat menjawab dengan benar secara matematis, namun untuk kemampuan menjawab lainnya diperoleh bahwa kemampuan mahasiswa menyelesaikan soal lebih tinggi dibandingkan guru baik secara trial-error maupun menjawab salah/tidak selesai. Selain itu, dari tabel tersebut juga diperoleh bahwa kemampuan menjawab dengan benar (secara matematis dan trial-error) kurang dari 50\%, atau lebih dari 50\% tidak mampu menjawab benar. Jadi, secara umum kemampuan mahasiswa dan guru pada materi pecahan adalah cukup.

Hasil analisis beberapa contoh jawaban mahasiswa dan guru dalam menyelesaikan soal pecahan tersebut, yaitu:

(1) Menjawab benar secara trial-error:

$$
\begin{array}{|lr|}
\frac{2}{x}+\frac{3}{y}=\frac{2}{3} ; x, y \in z & \\
6 y+9 x=2 x y & 6 y+9 x=2 x y \\
\text { Misalkan ambil nilai } y=3 \text {, maka } & 6 \cdot 3+9 x=2 x .3 \\
& 18+9 x=6 x \\
\text { Makca } x=-6 \text { 2an } x=3 & 9 x-6 x=-18 \\
\text { Bukti: } \frac{2}{x}+\frac{3}{y}=\frac{2}{3} & x=-6 \\
\frac{2}{-6}+\frac{3}{3}=\frac{2}{3} & \\
\frac{-1}{3}+\frac{3}{3}=\frac{2}{3} \text { terbukti } &
\end{array}
$$

Gambar 1. Jawaban benar secara trial-error

Pada Gambar 1 terlihat jawaban benar dengan cara memilih $x=6$ dan $y=3$. Pemilihan $x$ dan $y$ ini dilakukan secara langsung. Meski jawaban ini benar, namun jawaban tidak bersifat matematis karena tidak ada proses matematisnya, yaitu alasan dipilihnya $x=6$ dan $y=3$. Jawaban ini tentu saja membuat pembaca bertanya, kenapa dipilih $x=6$ dan bukan $x$ yang lain, demikian juga kenapa tidak dipilih $y$ lain dan bukan $y$
= 3. Sehingga jawaban ini benar tapi dianggap jawaban trial-error.

Sebenarnya, jawaban trial-error ber-nilai benar secara matematis jika memuat langkah-langkah matematis juga. Sebagai contoh, langkah-langkah jawaban trial-error adalah (a) anggap sisi kiri persamaan sebagai penjumlahan dua bilangan pecahan, (b) misalkan setiap bilangan pecahan bernilai $1 / 3$, sehingga jika dijumlahkan bernilai $2 / 3$, 
DOI: https://doi.org/10.24127/ajpm.v8i3.2349

dan (c) tentukan variabel $x$ dan $y$ pada masing-masing bilangan pecahan.

(2) Menjawab salah:

Pada Gambar 2, terlihat jawaban pada awalnya bersifat matematis. Namun, ada kesalahan konsep pada mensubtitusikan $x=\frac{2}{3} \quad$ ke persamaan pembilang. Langkah ini mengakibatkan diskriminan (D) negatif pada saat menentukan $y_{1.2}$ ? Jawaban ini memberikan informasi bahwa responden (mahasiswa/guru) kurang memahami cara substitusi/eleminasi pada penyelesaian persamaan.

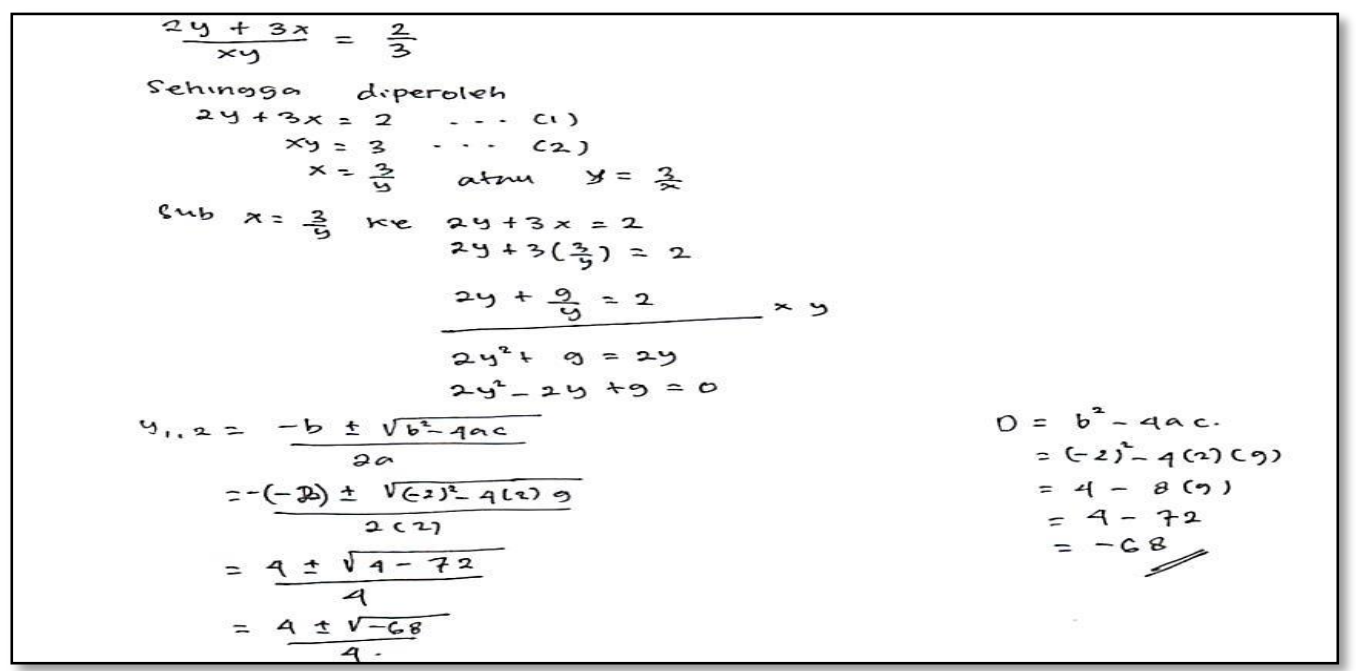

Gambar 2. Jawaban salah

(3) Menjawab tidak selesai:

Pada Gambar 3, jawaban tidak selesai ini karena mahasiswa dan guru tidak mampu memisalkan variabel $x$ dengan variabel $a$, dan variabel $y$ dengan $b$. Pemisalan variabel itu hanya kembali lagi ke bentuk awal. Jawaban ini memperlihatkan mahasiswa dan guru kurang memiliki kemampuan berpikir berani dan kreatif dengan mengambil nilai $x$ atau $y$ tertentu.

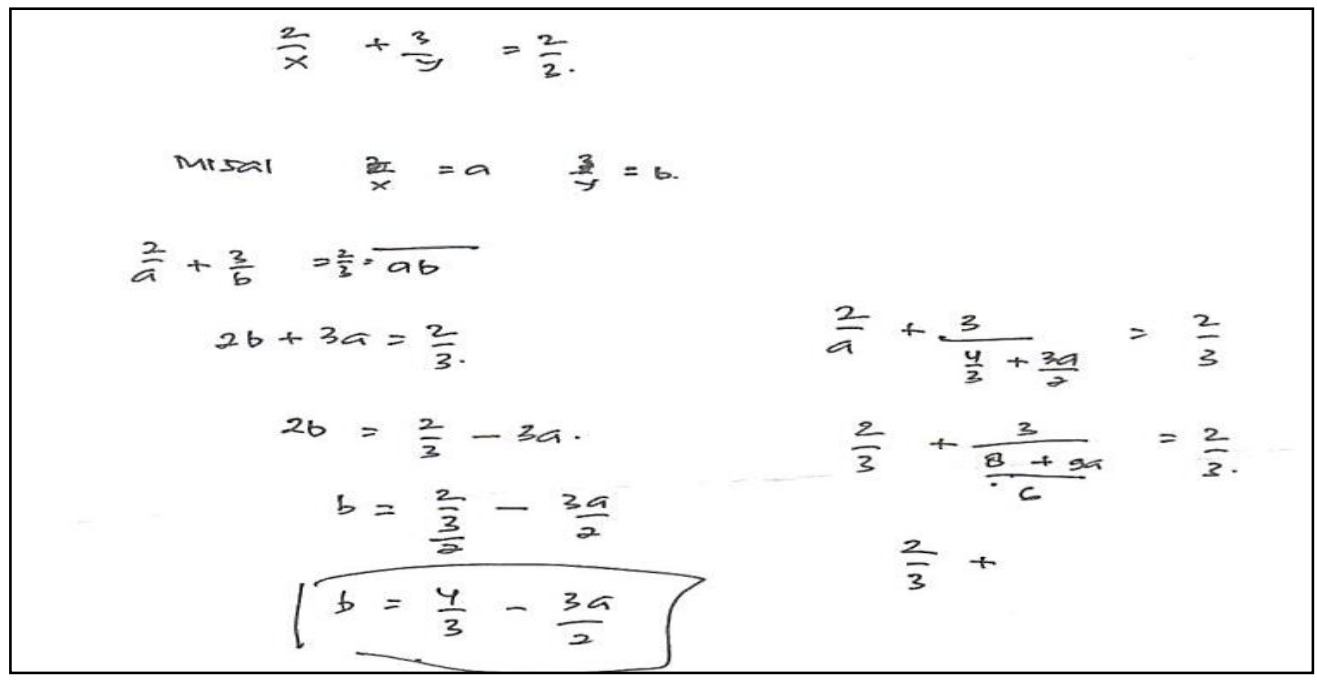

Gambar 3. Jawaban tidak selesai 
DOI: https://doi.org/10.24127/ajpm.v8i3.2349

2. Hasil wawancara mahasiswa dan guru

Wawancara terhadap mahasiwa dan guru dilakukan setelah pelaksanaan tes. Pertanyaan wawancaranya adalah "Kenapa soal $\frac{2}{x}+\frac{3}{y}=\frac{2}{3} ; x, y \in Z$ sulit diselesaikan?". Data hasil wawancara diidentifikasi dan dikelompokkan berdasarkan kemiripan ja-waban. Setelah data dianalisis, diperoleh empat jawaban yang mirip dari jawaban mahasiswa dan guru. Kemiripan jawaban mahasiswa dan guru bahwa penyebab sulitnya menyelesaikan soal pecahan tersebut adalah (a) banyak variabel lebih banyak daripada persamaan, (b) memi-sahkan variabel $x$ dan y pada sisi berbeda, (c) tidak mendapatkan solusi bulat, dan (d) tidak memberikan alasan. Rangkuman ha-sil identifikasi dan pengelompokkan disajikan pada Tabel 3.

Tabel 3. Penyebab sulit menyelesaikan soal pecahan

\begin{tabular}{|c|c|c|c|}
\hline \multirow[b]{2}{*}{ No } & \multirow{2}{*}{$\begin{array}{l}\text { Penyebab Sulit } \\
\text { Menyelesaikan } \\
\text { Soal Pecahan }\end{array}$} & \multicolumn{2}{|c|}{ Banyak } \\
\hline & & $\begin{array}{c}\text { Mahasiswa } \\
(\%)\end{array}$ & $\begin{array}{c}\text { Guru } \\
(\%)\end{array}$ \\
\hline 1 & $\begin{array}{l}\text { Variabel lebih } \\
\text { banyak daripada } \\
\text { persamaan }\end{array}$ & $\begin{array}{c}29 \\
(72,5 \%)\end{array}$ & $\begin{array}{c}22 \\
(73,3 \%)\end{array}$ \\
\hline 2 & $\begin{array}{l}\text { Memisahkan } \\
\text { variabel x dan y } \\
\text { pada sisi } \\
\text { berbeda }\end{array}$ & $\begin{array}{c}5 \\
(12,5 \%)\end{array}$ & $\begin{array}{c}2 \\
(6,7 \%)\end{array}$ \\
\hline 3 & $\begin{array}{l}\text { Tidak } \\
\text { mendapatkan } \\
\text { solusi bulat }\end{array}$ & $\begin{array}{c}6 \\
(15 \%)\end{array}$ & $\begin{array}{c}6 \\
(20 \%)\end{array}$ \\
\hline
\end{tabular}

Berdasarkan Tabel 3, penyebab ter-banyak sulitnya mahasiswa dan guru menyelesaikan soal pecahan adalah variabel lebih banyak daripada persamaan. Jawaban mahasiswa dan guru ini menunjukkan bahwa soal tersebut berbentuk 'baru' (non rutin), atau pertama kali menyelesaikan soal tersebut. Ketika menghadapi soal yang baru, umumnya mahasiswa dan guru kurang memiliki keberanian melakukan coba-coba (trial-error) dalam menyelesaikan soal. Padahal ketika kuliah, mahasiswa dan guru pernah menyelesaikan soal dengan variabel lebih banyak daripada persamaan (persamaan linear).

Biasanya, suatu soal yang variabel lebih banyak daripada persamaan memiliki dua kemungkinan solusi, yaitu satu solusi dan banyak solusi. Untuk menen-tukan $x$ dan $y$ pada soal ini memang dibutuhkan kreativitas untuk mencari berbagai alternatif $x$ dan $y$ yang memenuhi persamaan itu. Kreativitas merupakan salah satu kemampuan yang diperlukan dalam mempelajari matematika, terutama ketika menyelesaikan soal. Pada kasus ini, terlihat bahwa mahasiswa dan guru kurang memiliki kemampuan kreativitas saat menyelesaikan soal. Padahal kemampuan kreativitas ini dapat ditumbuhkan dan dikembangkan pada mahasiswa dan guru. Beberapa cara mengembangkan kemam-puan kreativitas siswa, seperti melakukan pembelajaran model discovery learning (Purwaningrum, 2016) dan brain storming, menggunakan media pembelajaran yang bervariasi, dan menata lingkungan belajar yang kondusif (Kenedi, 2017)

Penyebab kedua adalah sulit memi-sahkan variabel $x$ dan $y$ pada sisi berbeda. Pada soal ini terdapat penyebut yang memiliki dua variabel sehingga pada saat menyamakan penyebutnya menjadi $x y$. Selanjutnya, mengalikan pembilang sisi kiri dengan penyebut sisi kanan, dan mengalikan penyebut sisi kiri dengan pembilang sisi kanan. Berikut proses perhitungannya, yaitu: 
DOI: https://doi.org/10.24127/ajpm.v8i3.2349

$$
\begin{aligned}
& \frac{2}{x}+\frac{3}{y}=\frac{2}{3} \leftrightarrow \frac{2 y+3 x}{x y}=\frac{2}{3} \leftrightarrow 2 x y=6 y+9 x \leftrightarrow \\
& y=\frac{6 y+9 x}{2 x}
\end{aligned}
$$

Pada sisi kiri variabel $y$ sudah terpisah dengan $x$, namun pada sisi kanan terdapat terdapat $x$ dan $y$. Kondisi ini membuat mahasiswa dan guru sulit memisahkan variabel $x$ dan $y$. Demikian pula, ketika pada sisi kanan ingin memisahkan variabel $x$ dengan $y$ maka di sisi kiri akan tetap memiliki variabel $x$ dan $y$. Agar dapat memisahkan kedua varibel $x$ dan $y$, maka mahasiswa dan guru itu harus mampu memanipulasi operasi aljabar. Manipulasi operasi aljabar adalah kemampuan memanipulasi empat operasi utama aljabar, yaitu penjumlahan, pengurangan, perkalian, dan pembagian. Kemampuan manipulasi operasi aljabar mempengaruhi ke-mampuan penalaran matematis, atau dengan kata lain jika kemampuan manipulasi operasi aljabar seseorang baik maka akan baik juga kemampuan penalaran matematisnya, dan sebaliknya semakin rendah kemampuan manipulasi maka akan kurang juga kemampuan penalaran matematis (Suprihatingsih, Sijadi, \& Sari, 2014).

Penyebab ketiga adalah tidak mendapatkan solusi bulat (real/imaginer). Kesulitan ini disebabkan oleh ketidakmam-puan mahasiswa dan guru saat manipulasi operasi aljabar. Banyak faktor yang menyebabkan sulitnya siswa memanipulasi operasi aljabar. Penyebab sulitnya melakukan operasi aljabar siswa adalah kesulitan dalam menuliskan syarat perlu dan cukup, kesulitan dalam memahami suku, variabel, dan konstanta (Limardani, Trapsilasiwi, \& Fatahillah, 2015), kesalahan prosedural pada materi aljabar, yaitu ada suku yang tidak dikalikan dengan pengali, kesalahan dalam penggabungan penjumlahan, dan tidak dapat melakukan penyederhanaan (Ramadhani, Yuwono, \& Muksar, 2016), penyebab lain sulitnya melakukan operasi aljabar adalah kesalahan penulisan dan penggunaan tanda dan kesalahan dalam melakukan algoritma (Rosmaiyadi, 2018).

Beberapa temuan penting dalam penelitian ini, yaitu meski mahasiswa dan guru sudah mempelajari atau mengajarkan materi pecahan namun sebagian besar mahasiswa dan guru tersebut masih kelemahan/kekurangan dalam memodifikasi bentuk aljabar, mencari berbagai alternatif penyelesaian soal, dan memisahkan dua variabel ( $x$ dan $y$ ). Temuan tersebut diperoleh saat dilakukan wawancara kepada mahasiswa dan guru. Kelemahan atau kekurangan mahasiswa dan guru dalam memodifikasi bentuk aljabar disebabkan oleh lemahnya penguasaan sifat dan operasi aljabar. Mahasiswa dan guru merasa ragu saat menggunakan sifat dan operasi aljabar, seperti sifat asosiatif, distributif, komutatif, dan cancelled (pencoretan).

Lemahnya kemampuan mencari berbagai alternatif penyelesaian soal oleh mahasiswa dan guru ditunjukkan oleh sebagian besar (kurang dari 50\%) maha-siswa dan guru menjawab trialerror ketika tidak dapat menyelesaikan dengan cara matematis. Lemahnya kemampuan ini disebabkan oleh tidak terbiasanya mahasiswa dan guru berpikir kritis dan kreatif. Kemudian, lemahnya memisahkan dua variabel ( $x$ dan $y$ ) oleh mahasiswa dan guru diperlihatkan pada saat variabel $x$ dan $y$ berbentuk ( $x y)$ pada kedua sisi. Kesulitan ini disebabkan oleh lemahnya pemahaman konsep persamaan (linear dan nonlinear). 
DOI: https://doi.org/10.24127/ajpm.v8i3.2349

\section{KESIMPULAN DAN SARAN}

Hasil penelitian menyimpulkan bahwa kemampuan mahasiswa dan guru dalam menyelesaikan soal pecahan berada pada level kurang, cukup, dan baik, serta penyebab sulitnya mahasiswa dan guru menyelesaikan soal pecahan tersebut adalah variabel lebih banyak daripada persamaan, memisahkan variabel $x$ dan $y$ pada sisi berbeda, dan tidak mendapatkan solusi bulat. Selain itu, diperoleh temuan penting pada penelitian ini, yaitu masih kelemahan/kekurangan dalam memodifikasi bentuk aljabar, mencari berbagai alternatif penyelesaian soal, dan memisahkan dua variabel ( $x$ dan $y$ ).

Berdasarkan hasil penelitian tersebut maka disarankan kepada mahasiswa dan guru hendaknya memahami konsep dan operasi pecahan lagi, serta melatih diri untuk kritis dan kreatif menyelesaikan soal pecahan; kepada penyusun kurikulum hendaknya mengkaji kembali menempatkan materi pecahan yang disesuaikan dengan usia kognitif siswa, seperti materi pecahan diajarkan paling cepat siswa kelas 4 (bukan kelas 3); dan kepada peneliti lain hendaknya mengkaji kemampuan pecahan pada siswa jenjang SMA agar diperoleh gambaran yang utuh tentang kemampuan siswa tentang pecahan mulai siswa SD hingga perguruan tinggi.

\section{DAFTAR PUSTAKA}

Bruce, C., Chang, D., \& Flynn, T. (2013). Foundations to Learning and Teach-ing Fractions: Addition and Sub-traction. Diambil kembali dari http:// www.edugains.ca/
Grossberg, B. (2017). Why Learning Fractions is Important? Diambil kembali dari http://www.thoughco. com

Haji. (2013). Pendekatan Iceberg dalam Pembelajaran Pembagian Pecahan di SD. Infinity Journal, 2(1): 7584.

Karmawati. (2010). Analisis Kesalahan Siswa Kelas VI SD dalam Menyelesaikan Soal-Soal Matematika Berdasarkan Kompetensi yang Sulit pada UASBN. Tahun Pelajaran 2007/2008 di Kecamatan Limboto. Thesis. Universitas Negeri Yogyakarta

Kenedi. (2017). Pengembangan Kreativitas Siswa dalam Proses Pembelajaran di Kelas II SMP Negeri 3 Rokan IV Koto. Jurnal Pendidikan Sosial, Sains, dan Humaniora, 3(2): 329-347.

Koll, H., \& Mills, S. (2015). Understand-ing Maths: Fractions. UK: Schofield \& Sims Ltd.

Limardani, G., Trapsilasiwi, D., \& Fatahillah, A. (2015). Analisis Kesulitan Siswa dalam Menyelesaikan Soal Operasi Aljabar Berdasarkan Pemahaman Skemp pada Siswa Kelas VIII SMA Negeri 4 Jember. Artikel Ilmiah Mahasiswa, 1(1): 1-7.

Purwaningrum, J. P. (2016). Mengembangkan Kemampuan Berpikir Ma-tematis melalui Discovery Learn-ing Berbasis Scientific Approach. Jurnal Refleksi Edukatika, 6(2): 145-157. 
DOI: https://doi.org/10.24127/ajpm.v8i3.2349

Rahmawati. (2017). Desain Pembelajaran Penjumlahan dan Pengurangan Pecahan dengan Menggunakan Timbangan Siswa Kelas VI. Jurnal Pendidikan Matematika , 11(1): 7-68.

Ramadhani, A. N., Yuwono, I., \& Muksar, M. (2016). Analisis Kesalahan Siswa Kelas VIII SMP pada Materi Aljabar serta Proses Scaffoldingnya. Jurnal Silogisme: Kajian Ilmu Matematika dan Pembelajarannya, 1(1): 11-22.

Ramlah, Bennu, S., \& Paloloang, B. (2016). Analisis Kesalahan Siswa dalam Menyelesaikan Soal Penjumlahan dan Pengurangan Pecahan di Kelas VII SMPN Model Terpadu Madani. Jurnal Ilmiah Pendidikan Matematika, 1(2): 182-194.

Rosmaiyadi. (2018). Analisis Kesalahan Penyelesaian Soal Aljabar pada Mahasiswa Program Studi Pendidikan Matematika STKIP Singkawang. Jurnal Pendidikan Matematika, 12(1): 59-70.

Sahriah, S., \& Muksar, M. (2012). Analisis Kesalahan Siswa dalam Menyelesaikan Soal Matematika Materi Operasi Pecahan Bentuk Aljabar Kelas VIII SMPN 2 Malang. Jurnal Pendidikan Matematika, 1(1): 1-10.
Suprihatingsih, S., Sijadi, I., \& Sari, D. (2014). Penalaran Matematis Siswa dalam Pemecahan Masalah pada Ma-teri Poko Faktorisasi Bentuk Aljabar di Kelas VIII SMP Negeri I Surakar-ta. Jurnal Elektronik Pembelajaran Matematika, 2(7): 750-757.

Suryowati, E. (2015). Kesalahan Siswa SD dalam Mempresentasikan Pecahan pada Garis Bilangan. AKSIOMA: Jurnal Program Studi Pendidikan Matematika, 4(1): 3851.

Sutiarso, S., Asnawati, R., \& Jalil, A. (2017). Meningkatkan Teknik Meng-ajar Matematika melalui Lesson Study. Bandar Lampung: Tidak di-terbitkan.

Trivena, V., Ningsih, A., \& Jupri, A. (2017). Misconception on Addition and Subtraction of Fraction at Pri-mary School Student in Fifth-Grade. Proceeding of International Confer-ence on Mathematics and. 